\title{
THE EFFECT OF JIGSAW TYPE OF COOPERATIVE MODEL ON THE LEARNING OUTCOMES OF STUDENTS SOCIAL SCIENCE IN ELEMENTARY SCHOOL
}

\author{
Ully Fauziah ${ }^{1}$, Taufina Taufina ${ }^{2}$ \\ 1,2 Universitas Negeri Padang \\ 1ullyfauziah@yahoo.com, ${ }^{2}$ Taufina@unp.ac.id
}

\begin{abstract}
This research aims to determine the effect of Jigsaw Cooperative learning on student learning outcomes in social studies learning in grade 5 of elementary school. This research was motivated by the fact that teachers tended to apply conventional learning models, learning was often dominated by teachers, so the learning process was less attractive to students, and student learning outcomes in social studies learning still tended to be low. This research was a quantitative research with quasy experimental research design. The sampling was taken by using purposive sample technique. The research sample consisted of 50 people with a population of 50 people. The treatment that researchers gave to the experimental class aimed to determine the effect that occurred on learning outcomes using the Jigsaw Cooperative Learning Method. The instrument used in collecting data in the form of objective tests with multiple choice forms. Based on the research that has been done, the obtained t-count $>t$-table was $4.5378>2.011$ with $\alpha$ $=0.05$ which meant that $\mathrm{HO}$ was rejected. The average student learning outcomes measured by posttest after learning, namely in the 86.88 experimental class and 75.63 control class. So Ha accepted that there was an influence of the use of Jigsaw Cooperative learning model on student learning outcomes in social studies learning in grade 5 of elementary school.
\end{abstract}

Keywords: sosial science, cooperatif learning type jigsaw, learning outcomes

\section{PENGARUH MODEL KOOPERATIF TIPE JIGSAW TERHADAP HASIL BELAJAR IPS SISWA DI SEKOLAH DASAR}

\begin{abstract}
ABSTRAK
Penelitian ini bertujuan untuk mengetahui pengaruh pembelajaran Kooperatif Tipe Jigsaw terhadap hasil belajar siswa pada pembelajaran IPS di Kelas V SD. Penelitian ini dilatarbelakangi kenyataan bahwa guru cenderung menerapkan model pembelajaran konvensional, pembelajaran sering didominasi oleh guru, sehingga proses pembelajaran kurang menarik bagi siswa, dan hasil belajar siswa pada pembelajaran IPS masih cenderung rendah. Penelitian ini merupakan penelitian kuantitatif dengan jenis desain penelitian quasy eksperimen. Pengambilan data sampel dilakukan dengan menggunakan teknik purposive sample. Sampel penelitian ini berjumlah 50 orang dengan populasi sebanyak 50 orang. Perlakuan yang peneliti berikan kepada kelas eksperimen bertujuan untuk mengetahui pengaruh yang terjadi terhadap hasil belajar dengan menggunakan metode pembelajaran Kooperatif Tipe Jigsaw. Instrumen yang digunakan dalam mengumpulkan data berupa tes objektif dengan bentuk pilihan ganda. Berdasarkan penelitian yang telah dilakukan, maka diperoleh $t_{\text {hitung }}>t_{\text {tabel }}$ yakni $4.5378>2.011$ dengan $\alpha=0.05$ yang berarti $H_{0}$ ditolak. Rata-rata hasil belajar siswa yang diukur dengan posttest setelah dilakukan pembelajaran, yakni pada kelas eksperimen 86.88 dan kelas kontrol 75.63. Sehingga $H_{a}$ diterima yaitu terdapat pengaruh penggunaan model pembelajaran Kooperatif Tipe Jigsaw terhadap hasil belajar siswa pada pembelajaran IPS di kelas V SD
\end{abstract}

Kata Kunci: IPS, kooperatif tipe jigsaw, hasil belajar

\begin{tabular}{|c|c|c|}
\hline Submitted & Accepted & Published \\
\hline 31 Mei 2020 & 14 Juli 2020 & 24 Juli 2020 \\
\hline
\end{tabular}

\begin{tabular}{|l|c|c|c|}
\hline Citation & $:$ & $\begin{array}{r}\text { Fauziah, U., \& Taufina. (2020). The Effect of Jigsaw Type of Cooperative Model on The Learning Outcomes of Students } \\
\text { Social Science in Elementary School. Jurnal PAJAR (Pendidikan dan Pengajaran), 4(4), 771-779. DOI : } \\
\text { http://dx.doi.org/10.33578/pjr.v4i2.8031. }\end{array}$ \\
\hline
\end{tabular}

\section{PENDAHULUAN}

Pembelajaran IPS adalah satu dari beberapa bidang study yang diajarkan di Sekolah Dasar/Madrasah Ibtidaiyah (SD/MI). IPS diajarkan supaya siswa memperoleh bekal kemampuan dasar, baik pengetahuan dan

keterampilan untuk mengembangkan dirinya sesuai dengan keadaan lingkungan dalam kehidupan sehari-hari. Melalui IPS, peserta didik dibimbing agar mampu menjadi individu yang demokratis, memiliki tanggung jawab yang tinggi, 
serta menjadi warga negara yang cinta kedamaian dan ketentraman (Cahyo, 2018:28).

Pembelajaran IPS diharapkan dapat mengembangkan kemampuan siswa agar memiliki kepekaan terhadap permasalahan yang terjadi di lingkungannya, mempunyai sifat-sifat positif, dan siaga dalam mencari pemecahan dari permasalahan yang ada dalam keseharian, apakah berupa permasalahan yang terjadi pada dirinya sendiri ataupun yang menimpa lingkungan masyarakat disekitarnya (Susanto, 2016:148). Pola pembelajaran IPS tidak hanya sebatas pada upaya memberikan peserta didik dengan sejumlah konsep yang bersifat hafalan belaka. Melainkan lebih pada upaya agar peserta didik mampu menjadikan apa yang dipelajarinya sebagai bekal dalam memahami, dan ikut serta dalam menjalankan kehidupan bermasyarakat yang beragam (Tibahary \& Muliana, 2018). Namun IPS sering kali dianggap sebagai suatu pembelajaran yang menuntut hafalan materi sehingga menjadi membosankan (Ratri, 2018:2-3). Tak hanya itu IPS saat ini dianggap kurang menarik untuk dipelajari, hal inilah yang memberikan dampak terhadap rendahnya kemauan, respon dan antusiasme peserta didik pada saat proses belajar mengajar (Herijanto, 2012:9). Permasalahan lainnya dalam pembelajaran IPS juga muncul dari guru dalam pemilihan strategi, model, maupun metode pembelajaran, sehingga kurangnya ketertarikan siswa untuk belajar. Hal ini jugalah yang menyebabkan pada saat belajar, motivasi dan keaktifan siswa menjadi berkurang (Hertiavi dkk., 2010: 53).

Agar terwujudnya tujuan pembelajaran IPS tersebut maka guru sebagai pendidik harus terampil dalam menciptakan lingkungan belajar yang kondusif agat mutu belajar menjadi lebih baik. Guru sebagai pendidik sangat berperan penting dan sangat menentukan dalam meningkatkan kualitas pendidikan, karena guru terlibat langsung pada kegiatan belajar mengajar (Sihombing, 2019). Mulai dari menyusun rencana pembelajaran, perumusan tujuan pembelajaran yang disesuaikan dengan tingkatan perkembangan dan karakteristik siswa, penyediaan media ajar yang menarik dan sumber belajar beragaman, hingga kemampuan guru agar dapat menciptakan suasana lingkungan belajar kondusif, mengelola kelas yang nyaman, dan menyesuaikan model pembelajaran sesuai materi.

Model Jigsaw adalah satu dari beberapa model pembelajaraan kooperatif artinya pembelajaran dengan membuat kelompokkelompok. Secara umum, model ini merupakan model belajar kelompok kecil beranggotakan empat hingga lima orang dengan keberagaman latar belakang. Setiap anggota kelompok kecil mempelajari sebuah topik dan bertanggungjawab menyampaikan materi yang telah didapat nantinya pada anggota kelompok lain (Hamdayama, 2014: 87). Model pembelajaran kooperatif merupakan model pembelajaran yang bersifat student center, dimana siswa dituntut untuk lebih aktif dalam proses pembelajaran (Ardinastiti \& Santoso, 2016). Belajar kooperatif dirasa dapat mengembangkan tujuan akademik, dan nonakademik seperti hubungan antara perseorangan dengan individu lain dan kerjasama antar tim atau kelompok (Alsa, 2010:166). Model Jigsaw ini melatih siswa untuk memiliki sikap tanggung jawab. Sebab dalam model ini, pembelajaran dilakukan dengan cara berkelompok dan kelompok-kelompok tersebut disusun berdasarkan latar belakang yang berbeda. Masingmasing anggota akan diberikan tugas untuk menguasai materi yang berbeda, kemudian tiaptiap anggota kelompok mempertanggungjawabkan materi yang telah didapat tadi untuk disampaikan kepada anggota kelompok lainnya. Sehingga dalam setiap tahapan kegiatan model ini sangat memerlukan kemampuan dan keterampilan secara kognitif dan sosial (Herawani, 2019: 373).

Kelebihan model Kooperatif Tipe Jigsaw ini yakni model yang fleksibel. Beberapa kelebihan model tersebut yakni melatih siswa untuk mempunyai sikap yang mengarah pada karakter positif dalam kegiatan belajar dan membiasakan peserta didik untuk menghargai keberagaman pendapat dan gagasan orang lain, serta siswa yang terlibat didalam proses belajar mengajar akan mendapatkan hasil yang lebih baik (Rusman, 2015). Pembelajaran kooperatif juga dapat mengembangkan hubungan antara peserta didik dengan latar belakang yang beragam dan berbeda pada setiap teman sekelas mereka (Slavin, 
2015: 5). Kemampuan siswa saat bicara di depan kelas juga menjadi salah satu efek positif dari penggunaan model pembelajaran ini, siswa menajdi lebih aktif dalam mengemukakan gagasannya didean teman-teman mereka (Yusuf et al., 2020).

Berdasarkan observasi di kelas V di sebuah sekolah dasar yang ada di Kabupaten Agam yakni SDN 13 Cingkariang. Diperoleh data bahwa pada pembelajaran IPS biasanya guru cenderung menggunakan model konvensional. Di samping itu proses pembelajaran juga terlihat cenderung didominasi guru yang menerangkan, guru lebih banyak mengajar dengan berceramah, bercerita atau menugaskan siswa secara mandiri membaca materi di dalam buku karena materi IPS umumnya memang bersifat hafalan. Disamping itu model ataupun metode belajar yang dipilih oleh guru masih kurang bervariasi dan monoton, serta juga kegiatan belajar masih jarang dilakukan dengan cara berkelompok.

Pada siswa ditemukan masalah seperti siswa kurang berinteraksi didalam proses belajar,siswa juga kurang tertarik dan bersemangat

\section{METODE PENELITIAN}

Pada penelitian berjenis eksperimen ini dilakukan dengan desain quasi eksperiment yakni desain eksperimen yang mempunyai kelompok kontrol tapi tidak bisa melakukan kontrol variabelvariabel luar yang kemungkinan akan memberikan pengaruh pelaksanaan eksperimen itu sendiri (Sugiyono, 2012: 114). Adapun desain yang digunakan berupa Nonequivalent control group design. Oleh karena itu dalam pelaksanaannya menggunakan siswa kelompok eksperimen dan siswa kelompok kontrol. Tujuan penelitian kuantitatif eksperimen ini dilakukan yakni untuk menganalisis pengaruh model Jigsaw terhadap hasil belajar terutama pada pembelajaran IPS. Variabel dalam penelitian ini terdiri dari variabel independen atau bebas, dan variabel dependen atau terikat. dalam penelitian ini yang merupakan variabel bebas adalah model kooperatif tipe Jigsaw, sedangkan variabel terikat adalah hasil belajar siswa. dalam belajar, siswa kurang terampil dalam mengemukakan gagasan ataupun menemukan dan memecahkan masalah sendiri, serta pembiasaan peserta didik melakukan kegiatan diskusi kelompok. Dalam kegiatan diskusi secara berkelompok, peserta didik masih kurang mampu untuk bekerjasama dalam kelompoknya. Siswa yang pintar akan cenderung aktif dan mendominasi didalam kelompok, sementara siswa yang kurang pintar tidak begitu aktif dalam diskusi dan tidak mau mengemukakan gagasannya. Hal tersebut memberi dampak kurang baik terhadap output belajar yang menyebabkan hasil belajar cenderung masih rendah.

Berdasarkan masalah-masalah yang dipaparkan tersebut, peneliti tertarik melakukan penelitian dengan jenis quasi eksperiment dengan menggunakan model pembelajaran yakni model Kooperatif Tipe Jigsaw pada mata pelajaran IPS. Oleh sebab itu dalam penelitian ini akan dibahas tentang model kooperatif dengan mengangkat judul penelitian yaitu pengaruh Model Kooperatif Tipe Jigsaw terhadap hasil belajar IPS siswa di SD.

Penelitian yang dilakukan di SDN 13 Cingkariang Agam ini melibatkan populasi penelitian sebanyak 50 orang peserta didik yang terdiri dari seluruh siswa kelas V SDN 13 Cingkariang. Setelah dilakukan penarikan sampel dengan teknik purposive sampling didapat sampel pada penelitian yakni siswa kelas VA 25 orang serta siswa kelas VB yang 25 orang. Artinya total seluruh sampel adalah 50 siswa.

Teknik pengumpulan data pada penelitian ini dilakukan dengan cara tes. Adapun instrumen dalam penelitian ini terdiri dari soal objektif dengan bentuk multiple choice. Sebelum instrumen digunakan dalam penelitian, terlebih dahulu dilakukan analisis intrumen diantarnya : validitas, reliabilitas, daya beda, indeks kesuakaran, dan indeks pengecoh soal. Untuk menentukan valid tidaknya suatu alat ukur dalam penelitian ini digunakan rumus Korelasi Biserial. Untuk menentukan reliabilitas alat ukur dalam penelitian 
ini menggunakan rumus KR. 20 (Kuder Richardson).

Teknik analisis data dilakukan dengan menganalisis hasil belajar siswa yang diperoleh melalui tes tersebut bertujuan untuk menguji apakah hipotesis yang diajukan diterima atau ditolak. Untuk menganalisis data hasil belajar, digunakan uji kesamaan dua rata-rata uji-t.

\section{HASIL DAN PEMBAHASAN}

Penelitian dengan penerapan model pembelajaran Kooperatif Tipe Jigsaw merupakan sebuah penelitian eksperimen yang dilakukan di kelas V SD Negeri 13 Cingkariang. Data penelitian terdiri data primer dan data sekunder. Data primer diperoleh secara langsung dari hasil pretest dan posttest tentang materi IPS Kelas V yakni dengan menggunakan model pembelajaran Kooperatif Tipe Jigsaw pada kelas eksperimen, dan model pembelajaran konvensional pada kelas kontrol. Sedangkan data sekunder diperoleh dari nilai UTS Ganjil siswa kelas V SD Negeri 13 Cingkariang yang digunakan untuk menunjukkan bahwa hasil belajar siswa masih rendah.

Materi pembelajaran yang diajarkan pada kedua kelas adalah tentang perjuangan pahlawan dalam mempertahankan kemerdekaan yakni pada mata pelajaran IPS kelas V Sekolah Dasar. Sebelum dilaksanakan pembelajaran maka dilakukanlah pretest terlebih dahulu untuk
Sebelum uji kesamaan dua rata-rata terlebih dahulu dilakukan uji normalitas dan uji homogenitas dari kelas eksperimen dan kontrol sebagai prasyarat analisis. Setelah data hasil belajar memenuhi syarat baru setelah itu dilakukan uji hipotesis menggunakan uji-t untuk mengetahui apakah hipotesis diterima atau ditolak

mengetahui kemampuan dasar peserta didik pada masing-masing kelas. Pembelajaran dilaksanakan sebanyak tiga kali pertemuan pada masing-masing kelas yakni kelas VA sebagai kelas eksperimen dan VB sebagai kelas kontrol. Waktu pelaksanaan pembelajaran disamakan antara kedua kelas dengan artian jika pertemuan pertama dikelas ekperimen dilaksanakan dipagi hari maka pertemuan pertema di kelas kontrol juga dilaksanakan dipagi hari. Hal ini bertujuan untuk mengurangi pengaruh-pengaruh dari luar yang sifatnya dapat mempengaruhi perlakuan yang diberikan pada masing-masing kelas. Setelah kedua kelas selesai melaksanakan pembelajaran dengan model yang berbeda barulah dilaksakan posttest untuk mengumpulkan data yang akan dianalisis. Data pretest dan posttest di masingmasing kelas yang akan dianalisis disajikan pada tabel berikut :

Tabel 1. Nilai Pretest dan Posttest

\begin{tabular}{lcccc}
\hline & $\begin{array}{c}\text { Pretest Kelas } \\
\text { Eksperimen }\end{array}$ & $\begin{array}{c}\text { Postest Kelas } \\
\text { Eksperimen }\end{array}$ & $\begin{array}{c}\text { Pretest Kelas } \\
\text { Kontrol }\end{array}$ & $\begin{array}{c}\text { Postest Kelas } \\
\text { Kontrol }\end{array}$ \\
\hline N & 25 & 25 & 25 & 25 \\
Nilai maksimun & 68.8 & 100 & 71.9 & 90.6 \\
Nilai minimum & 34.3 & 68.8 & 43.8 & 56.3 \\
Rata-rata & 55.01 & 86.88 & 56.01 & 75.63 \\
\hline
\end{tabular}

Berdasarkan tabel 1 tersebut, diketahui bahwa dari nilai pretest didapat rata-rata pada kelas eksperimen 55.01 sedangkan dikelas kontrol adalah 55.01. Dengan demikian didapat informasi bahwa rata-rata pretest kelas kontrol nilainya lebih tinggi 1.00 dari kelas eksperimen. Selanjutnya diberikan treatment berupa guru mengajar dengan model kooperatif jigsaw di kelas eksperimen, sedangkan pembelajaran dengan model konvensional dilakukan di kelas kontrol. Pada masing-masing kelas sama-sama dilakukan proses pembelajaran yakni dengan pertemuan sebanyak 3 kali pada submateri yang sama. Soal pretest kedua kelas juga sama. Setelah diberikan treatmen barulah dilakukan posttest dan diketahui bahwa kelas eksperimen mendapatkan rata-rata posttest 
86.88 sedangkan kelas kontrol sebesar 75.63. Maka didapat kesimpulan bahwa rata-rata kelas kontrol lebih unggul 11.25 dari pada kelas eksperimen pada nilai posttest.

Namun, sebelum dilakukan analisis maka terlebih dulu dilakukan pengujian prasarat analisis diantaranya uji normalitas untuk mengetahui data yang akan diuji apakah memiliki sebaran nilai yang normal. Dalam hal ini digunakanlah uji Liliefors berbasis Microsoft Excel 2010 untuk melihat normalitas sebaran data, dengan menggunakan taraf signifikansi 5\%. Setelah dilakukan pengujian kemudian didapat hasil uji seperti berikut :

Tabel 2. Hasil Uji Normalitas Pretest

\begin{tabular}{lcccc}
\hline \multicolumn{1}{c}{ Kelas } & $\mathbf{N}$ & Lhitung & $\begin{array}{r}\text { Ltabel } \\
\boldsymbol{\alpha ~ 0 . 0 5}\end{array}$ & Hasil \\
\hline Eksperimen & 25 & 0.0982 & 0.173 & Berdistribusi Normal \\
Kontrol & 25 & 0.1636 & 0.173 & Berdistribusi Normal \\
\hline
\end{tabular}

Dari data yang ada pada tabel 2, diperoleh informasi bahwa kelas eksperimen memiliki Lhitung 0.0982 sedangkan kelas kontrol memiliki $\mathrm{L}_{\text {hitung }}$ 0.1636. Nilai $\mathrm{L}_{\text {tabel }}$ pada taraf signifikasi $5 \%$ adalah 0.173 . Itu artinya pada kelas eksperimen nilai $\mathrm{L}_{\text {hitung }}$ lebih kecil $\mathrm{L}_{\text {tabel}}$, begitu juga dengan kelas kontrol juga diperoleh $\mathrm{L}_{\text {hitung }}$ lebih kecil dari $\mathrm{L}_{\text {tabel. }}$ Maka dapat dibuat kesimpulan bahwa kedua kelas memiliki sebaran data yang normal.

Setelah dilakukan treatment pada kedua kelas dilakukanlah postest dengan hasil uji berikut:

Tabel 3. Hasil Uji Normalitas Posttest

\begin{tabular}{ccccc}
\hline Kelas & $\mathbf{N}$ & Lhitung & $\begin{array}{c}\text { Ltabel } \\
\boldsymbol{\alpha ~ 0 . 0 5}\end{array}$ & Hasil uji \\
\hline Eksperimen & 25 & 0.0862 & 0.173 & Berdistribusi Normal \\
Kontrol & 25 & 0.1153 & 0.173 & Berdistribusi Normal \\
\hline
\end{tabular}

Berdasarkan tabel 3, diperoleh informasi bahwa kelas eksperimen memiliki Lhitung 0.0862 sedang pada kelas kontrol didapatkan Lhitung 0.1153 . Nilai Ltabel pada taraf signifikasi $5 \%$ sebesar 0.173. Itu artinya nilai kelas eksperimen diperoleh Lhitung lebih kecil dari $\mathrm{L}_{\text {tabel}}$, yakni 0.0862 lebih kecil 0.173. Sedangkan pada kelas kontrol juga diperoleh nilai $\mathrm{L}_{\text {hitung }}$ lebih kecil dari pada $\mathrm{L}_{\text {tabel. }}$. Dengan demikian, dapat dibuat kesimpulan bahwasanya data berdistribusi normal untuk kedua kelas tersebut.
Langkah selanjutnya terhadap data yakni dilakukanlah uji homogenitas, dengan maksud melihat apakah sebaran data untuk kedua kelas sampel memiliki variansi data yang homogen atau tidak. Untuk itu uji homogenitas dilakukan menggunakan uji-F berbasis Microsoft Excel 2010. Dari hasil pengujian terhadap kedua kelas sampel maka diperoleh hasil pengujian homogenitas pretest sebagai berikut:

Tabel 4. Hasil Uji Homogenitas Pretest

\begin{tabular}{|l|c|c|c|c|c|}
\hline \multicolumn{1}{|c|}{ Kelas } & N & Variansi & F Fitung & Ftabel & Hasil uji \\
\hline Eksperimen & 25 & 93.4657 & 1.494 & 1.98 & Varian Homogen \\
\hline Kontrol & 25 & 62.5374 & & & \\
\hline
\end{tabular}

Dari tabel 4 diatas, diketahui bahwa $\mathrm{F}_{\text {hitung }}$ kelas sampel sebesar 1.494 sedangkan $\mathrm{F}_{\text {tabel }}$ adalah
1.98. Sehingga $F_{\text {hitung }}$ lebih kecil dari $F_{\text {tabel, }}$, yakni 1.494 lebih kecil dari 1.98. Maka dari itu, dapat 
dibuat kesimpulan bahwa data kedua kelas sampel memenuhi uji prasyarat karena variansi kedua kelas homogen.
Setelah dilakukan pengujian terhadap kedua kelas didapatlah hasil berikut:

Tabel 5. Hasil Uji Homogenitas Posttest

\begin{tabular}{|l|c|c|c|c|c|}
\hline \multicolumn{1}{c|}{ Kelas } & $\mathbf{N}$ & Varians & $\mathbf{F}_{\text {hitung }}$ & $\mathbf{F}_{\text {tabel }}$ & Hasil uji \\
\hline Eksperimen & 25 & 61.7975 & 1.486 & 1.98 & Varian Homogen \\
\hline Kontrol & 25 & 91.8014 & & & \\
\hline
\end{tabular}

Dari tabel 5 diatas, diketahui $\mathrm{F}_{\text {hitung }}$ kedua kelas adalah 1.486. Pada taraf signifikansi 5\% didapat $\mathrm{F}_{\text {tabel }}$ 1.98. Maka didapat nilai $\mathrm{F}_{\text {hitung }}$ lebih kecil dari $\mathrm{F}_{\text {tabel, }}$ yakni 1.486 lebih kecil dari 1.98. Maka dari itu dapat dibuat kesimpulan bahwa data kedua kelas untuk nilai postest memenuhi uji analisis prasayarat karena memiliki variansi yang homogen.

Setelah uji analisi prasyarat selesai dilakukan untuk sebaran data maka kedua data dikatakan memenuhi prasyarat tersebut barulah dilaukan uji hipotesis. Tujuan dilakukannya uji hipotesisyakni untuk melihat apakah hipotesis yang kita buat diterima ataukah ditolak. Pada kedua data dilakukan uji hipotesis menggunakan uji t yakni sampel uji bebas dua pihak.

Nilai posttest adalah nilai yang akan dipakai untuk analisis pengujian hipotesis, dan setelah dilakukan uji t dua pihak terhadap data tersebut maka didapatkan hasil seperti berikut ini:

Tabel 6. Hasil Uji T data Posttest kelas sampel

\begin{tabular}{|l|c|c|c|c|c|}
\hline \multicolumn{1}{|c|}{ Kelas } & $\mathbf{N}$ & Mean & Thitung & $\begin{array}{c}\mathbf{T}_{\text {tabel }} \\
\mathbf{a ~ 0 . 0 5 / 2}\end{array}$ & Hasil uji \\
\hline Eksperimen & 25 & 86.88 & 4.5378 & 2.011 & Ho ditolak. \\
\hline Kontrol & 25 & 75.63 & & & \\
\hline
\end{tabular}

Dari data pada tabel 6 tersebut diperoleh informasi bahwa nilai $t_{\text {hitung }} 4.5378$ sedangkan pada $\mathrm{t}_{\text {tabel }} 2.011$ pada taraf 5\%. Nilai 4.5378 lebih besar dari 2.011 itu artinya Ho ditolak dan Ha diterima. Maka dari itu, dibuatlah kesimpulan bahwasanya ada pengaruh yang signifikan dari model Kooperatif Jigsaw terhadap hasil belajar siswa.

Model kooperatif Jigsaw ini berlandasakan pada teori belajar humanistik yang menerangkan bahwa pada dasarnya setiap individu memliki keunikan potensi tersendiri untuk berkembang. Jigsaw memiliki keunggulan apabila dibandingkan model pembelajaran lain berupa meningkatkan kemampuan peserta didik untuk aktif saat berinteraksi, memiliki tanggung jawab dalam mengendalikan diri, menerapkan akhlak mulia serta karakter spiritual yang baik, serta memecahkan persoalan didalam masyarakat dengan terampil (Supranoto, 2017). Sementara bidang studi IPS bertujuan untuk pembentukan karakter pelaku sosial agar terjalinnya kehidupan yang harmonis (Supranoto, 2017). Dalam upaya pembentukan karakter itu sendiri diperlukanlah tanggung jawab dari dalam diri seseorang untuk mengarahkan potensi yang dimilikinya tersebut. Hendak menjadi seperti ada pirinya kelak ditengah-tengah kehidupan masyarakat. Oleh sebab itu model Jigsaw tersebut dirasa tepat dalam mengupayakan menumbuhkan rasa tanggungjawab peserta didik dalam proses belajar mengajar termasuk mengajar dirinya sendiri dan oranglain.

Langkah-langkah model Jigsaw yang dilakukan berupa: 1) Persiapan dimana siswa diberikan bahan materi akan didiskusikan; 2) Membagi siswa kedalam tim yang disebut kelompok asal secara heterogen; 3) Pembagian tim tersebut menjadi kelompok atau tim ahli dimana anggotanya dari tiap kelompok memahami subtopik sesuai jumlah kelompok yang ada; 4) Menentukan skor awal pertama dengan menggunakan nilai pre-test siswa; 5) Setiap kelompok membaca serta mendiskusikan topik- 
topik yang dibagi; 6) Kelompok ahli selanjutnya berdiskusi memecahkan topik serta menguasai topik tersebut; 7) Laporan tim dimana setiap ahli dari kelompok berkunjung ke kelompok lain dan kembali dengan membawa topik lain dari kelompok tersebut. Barulah setelah itu mereka menyampaikan topik di kelompoknya; 8) Tes atau kuis yang dilakukan secara individual namun nilai tersebut akan dijadikan acuan dalam penentuan skor kelompok; 9) Rekognisi tim dan penghargaan kelompok yang dihitung berdasarkan poin kemajuan siswa dari skor awal. (Slavin, 2015).

Sebelum dilaksanakannya penelitian dilihat terlebih dahulu gabaran kemampuan awal kedua kelas dengan melakukan pretest. Setelah diperoleh data pretest maka diuji normalitas dan homogenitasnya sebagai prasyarat data dapat dianalisis. Kelas VA yang merupakan kelas eksperimen diberi treatment model Kooperatif Tipe Jigsaw, dan di kelas VB menjadi kelas kontrol yang melakukan proses belajar mengajar dengan model konvensional. Materi ajar yang diberikan untuk kedua kelas adalah sama yakni tentang menghargai jasa para pahlawan kemerdekaan. Jumlah pertemuan kedua kelas pun sama yakni sama-sama 3 kali pertemuan diluar prestest. Untuk posttest sendiri langsung dilakukan dipertemuan ketiga setelah melaksanakan pembelajaran dengan masing-masing treatment.

Setelah itu barulah dilakukan postest terhadap kedua kelas sampel. Test tersebut dilakukan dengan instumen butir soal objektif. Data posttest tersebut nantinya akan digunakan untuk analisis uji hipotesis menggunakan uji t. kemudian setelah diadakannya posttest ternyata didapatkan bahwa thitung lebih besar dari tabel yakni 4.5378 lebih besar dari 2.011. Artinya Ho ditolak dan Ha diterima. Hasil dari penelitian menunjukkan bahwasanya ada pengaruh yang signifikan dari Model Kooperatif Jigsaw terhadap hasil belajar. Dari hasil data posttest yang telah diperoleh, diketahui informasi bahwa ada perbedaan yang cukup signifikan dimana pada kelas eksperimen rata-rata posttest lebih tinggi sebesar 11.25 dibandingkan pada kelas kontrol. Sehingga dapat dibuat kesimpulan bahwasanya ada pengaruh model kooperatif jigsaw terhadap hasil belajar siswa.

Model kooperatif membantu peserta didik dalam memahami materi secara berkelompok, model ini merupakan model belajar yang memupuk pembentukan kelompok kerja dengan lingkungan positif, meniadakan persaingan antar individu dan isolasi lingkungan akademik (Nizami, 2020). Dengan dilakukakannya pembelajaran secara berkelompok maka peserta didik dapat melatih diri sendiri untuk memliki rasa tanggung jawab yang besar untuk memahami materi dimana kemudian akan diteruskan kepada temennya yang lain. Model kooperatif jigsaw memliki keunikan tersendiri dibandingkan model kooperatif yang lain. Sebab dalam diksusi terdapat kelompok atau tim asal dan kelompok atau tim ahli. Selanjutnya anggota di kelompok ahli akan datang ke kelompok ahli lain untuk menemukan informasi. Setelah mereka mendapatkan informasi anggota kelompok akan kembali ke kelompok asal dengan tujuan menyampaikan materi yang telah mereka peroleh di kelompok tetangga tadi. Disinilah tanggung jawab masing-masing anggota kelompok diutamakan.

Guru dalam hal ini hanya bertugas memfasilitasi peserta didik, mengarahkan, membimbing dan membantu apabila peserta didik mengalami kesulitan dalam berdiskusi. Tak hanya itu, pada saat siswa berdiskusi terjalinlah komunikasi yang baik antara masing-masing anggota kelompok. Hal ini dapat melatih peserta didik memiliki keterampilan dalam berinteraksi dan menghargai pendapat orang lain. Peserta didik didalam kelompok juga akan saling membantu dan bekerjasama demi pencapaian nilai dalam kelompoknya, tiap kelompok akan bersaing dalam memperebutkan penghargaan sebagai kelompok super. Oleh karena itu mereka akan saling bahu membahu dan menyampingkan rasa individualisme dalam menuntaskan tugas dan tanggungjawab dalam kelompok masing-masing. 


\section{SIMPULAN DAN REKOMENDASI}

Merujuk pada hasil penelitian di kelas V SDN 13 Cingkariang tersebut, diketahui bahwa nilai posttest pada kelas eksperimen adalah 86.88 dan kelas kontrol sebesar 75.63 Kelas eksperimen yang dilakukan treatment yakni proses belajar mengajar dengan model kooperatif jigsaw memperoleh rata-rata yang lebih unggul jika dibandingkan kelas kontrol dengan model konvensional. Dimana selisish antara rata-rata dari kedua kelas adalah 11.25.

Kedua kelas diberikan treatmen yang berbeda setelah itu barulah dilakukanlah pengujian untuk menganalisis hasil posttest kedua kelas. Uji hipotesis dilakukan dengan tujuan melihat pengaruh dari treatment yang telah dilakukan. Besaran nilai $t_{\text {hitung }}$ adalah 4.5379 dan $\mathrm{t}_{\text {tabel }}$ sebesar

\section{DAFTAR PUSTAKA}

Alsa, A. (2010). Pengaruh Metode Belajar Jigsaw Terhadap Keterampilan Hubungan Interpersonal dan Kerjasama Kelompok pada Mahasiswa Fakultas Psikologi. Jurnal Psikologi, 37(2), 165-175. https://doi.org/10.22146/jpsi.7727

Ardinastiti, N., \& Santoso, A. B. (2016). Pengembangan Media Pembelajaran Ips Berbasis Macromedia Flash Materi Hidrosfer Menggunakan Model Pembelajaran Kooperatif Tipe Numbered Heads Together Kelas Vii Smp N 1 Secang Kabupaten Magelang. $E d u$ Geography, 4(1), 16-23.

Cahyo, dkk. (2018). Upaya Meningkatkan Hasil Belajar Ips Melalui Model Problem Based Learning (Pbl) Berbantuan Media Audio Visual Pada Siswa Kelas 4 Sd. Jurnal Basicedu, 2(1), 28-32. https://doi.org/10.31004/basicedu.v2i1.23

Hamdayama, J. (2014). Model dan Metode Pembelajaran Kreatif dan Berkarakter. Surabaya: Ghalia Indonesia.

Herawani, nellly. H. dan Y. F. (2019). Peningkatan Hasil Belajar Mengenal JenisJenis Pekerjaan Melalui Metode Jigsaw Dengan Media Pop Up Di Kelas III SDN
2.011 sehingga diketahui nilai thitung lebih besar dari ttabel yang menandakan bahwa Ho ditolak. Dengan demikian dapat dibuat kesimpulan ada pengaruh yang signifikan dari model kooperatif tipe jigsaw terhadap hasil belajar siswa.

Berdasarkan simpulan yang telah dibuat tersebut maka saran untuk guru agar menggunakan model kooperatif jigsaw sebagai suatu variasi model mengajar di dalam kelas, terutama bagi kelas yang memiliki jumlah siswa yang banyak. Tak hanya itu guru juga dapat menggunakan model ini dalam belajar untuk memupuk rasa tanggung jawab, peduli, kerjasama, dan meningkatkan rasa mandiri terhadap siswa. Hasil penelitian juga dapat dipakai sebagai acuan ataupun sebagai bahan referensi dalam penelitian lain.

11 Air Kalam. Jurnal basicedu, 3(2), 524532.

Herijanto, B. (2012). Pengembangan CD Interaktif Pembelajaran IPS Materi Bencana Alam. JESS (Journal of Educational Social Studies), https://doi.org/10.15294/jess.v1i1.73

Hertiavi, M. A., Langlang, H., \& Khanafiyah, S. (2010). Penerapan Model Pembelajaran Kooperatif Tipe Jigsaw Untuk Peningkatan Kemampuan Pemecahan Masalah Siswa Smp. Jurnal Pendidikan Fisika Indonesia, 6(1), 53-57. https://doi.org/10.15294/jpfi.v6i1.1104

Nizami. (2020). Application Of STAD Type Cooperative Learning Model To Improve Mathematics Learning Outcomes Elementary School Students. Jurnal PAJAR (Pendidikan dan Pengajaran), 4(1), 234-242.

Ratri, S. Y. (2018). Digital Storytelling Pada Pembelajaran IPS Di Sekolah Dasar. Jurnal Pena Karakter, 1(1), 1-8.

Rusman. (2015). Model-Model Pembelajaran. Jakarta: Rajawali Pers.

Sihombing, M. (2019). Peningkatan Hasil Belajar Ips Siswa Dengan Menerapkan Model Pembelajaran Kooperatif Tipe Examples 
Non Examples Di SD Negeri 019 Bumi Ayu. Jurnal PAJAR (Pendidikan dan Pengajaran), 3(November), 1226-1231.

Slavin, R. E. (2015). Cooperative Learning. Bandung: Nusa Media.

Sugiyono. (2012). Metode Penelitian Pendidikan. Bandung: Alfabeta.

Supranoto, H. (2017). Penggaruh Model Pembelajaran Jigsaw Terhadap Hasil Belajar Studi Masyarakat Indonesia Mahasiswa. Jurnal Pendidikan Ekonomi UM Metro, 5(1), 85.

Susanto, A. (2016). Teori Belajar dan Pembelajaran di Sekolah Dasar. Jakarta: Kencana.

Tibahary, A. R., \& Muliana. (2018). Model-Model Pembelajaran Inovatif. Journal of Pedagogy, 1(03), 54-64.

Yusuf, A. R., Kurniawan, S., Sutadji, E., \& Imam Sudijono. (2020). Impact Of Student Teams Achievement Division Based On Hybrid Learning And Jigsaw Toward High Order Thinking Skill Vocational High School. Jurnal PAJAR (Pendidikan dan Pengajaran), 4(3), 560-568. DOI : http://dx.doi.org/10.33578/pjr.v4i2.7971. 